\title{
Aerospace Fuels From Nonpetroleum Raw Materials
}

Bryan A. Palaszewski, Aloysius F. Hepp, Michael J. Kulis, and Donald A. Jaworske

Glenn Research Center, Cleveland, Ohio 


\section{NASA STI Program . . . in Profile}

Since its founding, NASA has been dedicated to the advancement of aeronautics and space science. The NASA Scientific and Technical Information (STI) program plays a key part in helping NASA maintain this important role.

The NASA STI Program operates under the auspices of the Agency Chief Information Officer. It collects, organizes, provides for archiving, and disseminates NASA's STI. The NASA STI program provides access to the NASA Aeronautics and Space Database and its public interface, the NASA Technical Reports Server, thus providing one of the largest collections of aeronautical and space science STI in the world. Results are published in both non-NASA channels and by NASA in the NASA STI Report Series, which includes the following report types:

- TECHNICAL PUBLICATION. Reports of completed research or a major significant phase of research that present the results of NASA programs and include extensive data or theoretical analysis. Includes compilations of significant scientific and technical data and information deemed to be of continuing reference value. NASA counterpart of peer-reviewed formal professional papers but has less stringent limitations on manuscript length and extent of graphic presentations.

- TECHNICAL MEMORANDUM. Scientific and technical findings that are preliminary or of specialized interest, e.g., quick release reports, working papers, and bibliographies that contain minimal annotation. Does not contain extensive analysis.

- CONTRACTOR REPORT. Scientific and technical findings by NASA-sponsored contractors and grantees.
- CONFERENCE PUBLICATION. Collected papers from scientific and technical conferences, symposia, seminars, or other meetings sponsored or cosponsored by NASA.

- SPECIAL PUBLICATION. Scientific, technical, or historical information from NASA programs, projects, and missions, often concerned with subjects having substantial public interest.

- TECHNICAL TRANSLATION. Englishlanguage translations of foreign scientific and technical material pertinent to NASA's mission.

Specialized services also include creating custom thesauri, building customized databases, organizing and publishing research results.

For more information about the NASA STI program, see the following:

- Access the NASA STI program home page at http://www.sti.nasa.gov

- E-mail your question to help@sti.nasa.gov

- Fax your question to the NASA STI Information Desk at 443-757-5803

- Phone the NASA STI Information Desk at 443-757-5802

- Write to: STI Information Desk NASA Center for AeroSpace Information 7115 Standard Drive Hanover, MD 21076-1320 
NASA/TM-2013-216492

AIAA-2013-0591

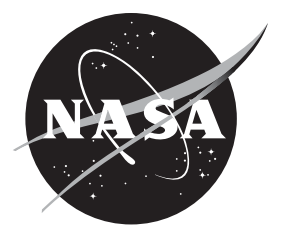

\section{Aerospace Fuels From Nonpetroleum Raw Materials}

Bryan A. Palaszewski, Aloysius F. Hepp, Michael J. Kulis, and Donald A. Jaworske Glenn Research Center, Cleveland, Ohio

Prepared for the

51st Aerospace Sciences Meeting

sponsored by the American Institute of Aeronautics and Astronautics

Grapevine, Texas, January 7-10, 2013

National Aeronautics and

Space Administration

Glenn Research Center

Cleveland, Ohio 44135 


\section{Acknowledgments}

The following students are acknowledged for their contribution(s) to this work during summer fellowships at NASA Glenn Research Center: Pierce Gordon, Karen Guerrero-Medina, Blain McLeod, and Thomaz Santana. We also acknowledge technical discussions with, and input from our colleagues, Ms. Diane Linne, Mr. Anthony Colozza, and Dr. Kurt Sacksteder.

This report contains preliminary findings, subject to revision as analysis proceeds.

Trade names and trademarks are used in this report for identification only. Their usage does not constitute an official endorsement, either expressed or implied, by the National Aeronautics and Space Administration.

Level of Review: This material has been technically reviewed by technical management.

Available from

NASA Center for Aerospace Information 7115 Standard Drive

Hanover, MD 21076-1320
National Technical Information Service 5301 Shawnee Road Alexandria, VA 22312

Available electronically at http://www.sti.nasa.gov 


\title{
Aerospace Fuels From Nonpetroleum Raw Materials
}

\author{
Bryan A. Palaszewski, Aloysius F. Hepp, Michael J. Kulis, and Donald A. Jaworske \\ National Aeronautics and Space Administration \\ Glenn Research Center \\ Cleveland, Ohio 44135
}

\begin{abstract}
Recycling human metabolic and plastic wastes minimizes cost and increases efficiency by reducing the need to transport consumables and return trash, respectively, from orbit to support a space station crew. If the much larger costs of transporting consumables to the Moon and beyond are taken into account, developing waste recycling technologies becomes imperative and possibly mission enabling. Reduction of terrestrial waste streams while producing energy and/or valuable raw materials is an opportunity being realized by a new generation of visionary entrepreneurs; several relevant technologies are briefly compared, contrasted and assessed for space applications. A two-step approach to nonpetroleum raw materials utilization is presented; the first step involves production of supply or producer gas. This is akin to synthesis gas containing carbon oxides, hydrogen, and simple hydrocarbons. The second step involves production of fuel via the Sabatier process, a methanation reaction, or another gas-to-liquid technology, typically Fischer-Tropsch processing. Optimization to enhance the fraction of product stream relevant to transportation fuels via catalytic (process) development at NASA Glenn Research Center is described. Energy utilization is a concern for production of fuels whether for operation on the lunar or Martian surface, or beyond. The term "green" relates to not only mitigating excess carbon release but also to the efficiency of energy usage. For space, energy usage can be an essential concern. Another issue of great concern is minimizing impurities in the product stream(s), especially those that are potential health risks and/or could degrade operations through catalyst poisoning or equipment damage; technologies being developed to remove heteroatom impurities are discussed. Alternative technologies to utilize waste fluids, such as a propulsion option called the resistojet, are discussed. The resistojet is an electric propulsion technology with a powered thruster to vaporize and heat a propellant to high temperature, hot gases are subsequently passed through a converging-diverging nozzle expanding gases to supersonic velocities. A resistojet can accommodate many different fluids, including various reaction chamber (by-)products.
\end{abstract}

\section{Nomenclature}

$\mathrm{C} 1$ generic term for simple one-carbon $\left(\mathrm{CO}, \mathrm{CO}_{2}, \mathrm{CH}_{4}\right)$ compounds

$\mathrm{CH}_{4} \quad$ chemical symbol for methane

$\mathrm{CO}$ chemical symbol for carbon monoxide

$\mathrm{CO}_{2} \quad$ chemical symbol for carbon dioxide

$\Delta \mathrm{G} \quad$ Gibbs free energy change

$\Delta \mathrm{H}$ enthalpy change, related to Gibbs free energy change: $\Delta \mathrm{G}=\Delta \mathrm{H}-\mathrm{T} \Delta \mathrm{S}$

F-T Fischer-Tropsch

F-T(S) Fischer-Tropsch (synthesis)

$\mathrm{H}_{2} \quad$ chemical symbol for molecular hydrogen

$\mathrm{H}_{2} \mathrm{O} \quad$ chemical symbol for water

ISRU In Situ Resource Utilization

PAG plasma assisted gasification

Syn-gas synthesis gas: Hydrogen/carbon monoxide gaseous mixture, typical ratio is 2-3:1

WTE waste-to-energy technologies 


\section{Introduction and Background}

As NASA moves forward with plans to support human exploration of the solar system, a critical need arises to supply basic raw materials such as food, other life support (water and oxygen), energy and propellants, and other materials (radiation shielding, clothing, etc.) (Ref. 1). Thus far, NASA has relied on materials brought from Earth; this conservative approach, while quite costly, minimizes risk to crews. As mankind ventures farther from Earth and for greater periods of time, it becomes imperative to develop technologies and mission architectures that utilize local resources such as Lunar regolith or Martian atmosphere, referred to as in-situ resource utilization or ISRU (Ref. 2). For a terrestrial analog, efficient utilization of raw materials and energy often involves recycling: re-use or recovery of hydrocarbons (or syngas, vide infra) from waste plastics (Ref.3). These relate to in-flight utilization of waste and trash to produce essential materials such as water, fuel(s), and oxygen. Lighter elements such as oxygen, nitrogen, and particularly carbon and hydrogen are either not readily available or strongly bonded to metal or metalloid atoms in rocks and minerals (especially oxygen) requiring significant energy for extraction (Ref. 4).

We have previously discussed specific technologies (catalysts, reactor technologies, solar energy and other green power sources) being developed at NASA Glenn Research Center (GRC) and through the efforts of partnering contractors and university collaborators to utilize nonpetroleum raw materials (Ref. 5). In this paper, we discuss the problem at hand, recycling waste and trash into useful raw materials, from a systems level with a view towards integration of subsystems, energy utilization, human factors, mission applicability, and opportunities for insertion of such disruptive technologies, to enable specific missions.

The organization that we will adopt is illustrated by Figure 1. The major concerns and issues that we will address are broken down into three areas that define the organization of the paper: preprocessing, waste and trash breakdown, and re-formation of products. Balance-of-system issues, energy efficiency, and related concerns will be addressed in a follow-on section. Insights to be gained from modeling and theoretical consideration of components, unit operations, and subsystems will then be discussed. We conclude with addressing potentially enabling new approaches and technologies for missions farther from Earth.

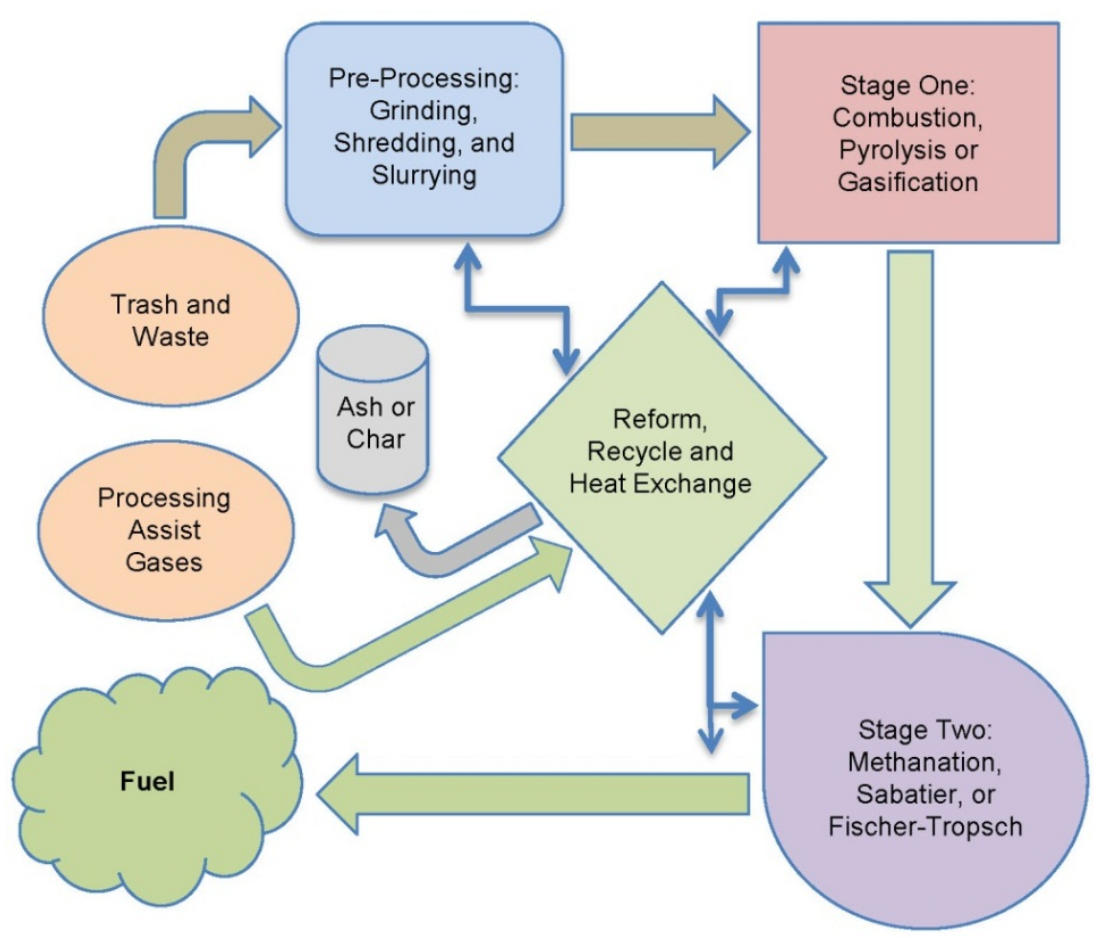

Figure 1.-Overview of generic process flow diagram for a Trash-to-Supply Gas system. 


\section{Overview of Major Processing Subsystems}

The general flow diagram above (Figure 1) serves as a platform for a discussion of technological road blocks and technical solutions. This is a top-level discussion with more in-depth analyses in following sections.

\section{Rationale and Goals for Modeling of Waste Materials Processing}

In the Advanced Exploration Systems-Logistics Reduction and Repurposing (LRR) program, modeling of various waste conversion processes is underway. Modeling will lead to an optimized flow and production rate for each of the processes. With this information, a down-select can be made amongst competing conversion methods. Many additional factors have been identified including waste production rate, process temperature and pressure (which can affect crew safety and lengthen the processing time), the unusable matter that may accumulate in the process components, and the time needed from the astronauts for charging and cleaning the process components. The complexity, safety, and the time scales for processing the waste materials may have a very strong influence on the selection process.

\section{Stage 1: Production of Supply Gas and/or Hydrocarbons Via Waste-to-Energy Technologies}

Plastic solid waste can be recycled or utilized via four major classes of processes, designated as primary to quaternary, respectively, as physical and/or chemical breakdown increases. These include recycling (primary) and mechanical recovery (secondary) that are not discussed further, chemical recycling (tertiary), and energy recovery (quaternary) (Ref. 3). Commercial processes including incineration (to directly produce electricity) (Ref. 6) and biologically-assisted digestion (Ref. 7) are outside of the scope of this discussion and will also not be addressed.

There have been numerous excellent reviews that summarize and analyze in detail the various technologies, products, energy balance, and economics of several mainstream waste-to-energy (WTE) technologies. Several example tertiary or quaternary processes include: chemical recycling via pyrolysis (thermal or catalytic cracking) to produce mostly higher hydrocarbons; gasification (thermal cracking in air and/or steam) to produce $\mathrm{CO}_{2}$ and syn-(thesis) gas $\left(\mathrm{CO}\right.$ and $\left.\mathrm{H}_{2}\right)$ and small amounts of oxygen, water, and methane, sometimes called producer gas (Ref. 8); and plasma-assisted gasification (also a quaternary process) (Ref. 3) that relies on a very high temperature plasma torch to produce primarily syn-gas.

A comparison of relevant technical details as well as energy utilization and the infrastructural requirements that determine suitability for a variety of space missions is detailed in Table I and includes thermal cracking, flash cracking, steam reformer/Sabatier, and plasma assisted/Fischer-Tropsch (F-T) (Ref. 9) reactors. The processes previously discussed (Ref. 5) being developed by RES Polyflow (tertiary) and Pioneer Astronautics (quaternary) are typical of these technologies that use heat in a variety of environments to break down polymers into a product soup. The Pioneer Astronautics process involves an integrated Sabatier process to produce methane but requires a hydrogen source. The rather complex plasma-assisted gasification process relies on quite high temperatures with a significant balance-ofsystem to recover thermal energies.

While it is difficult to make direct comparisons regarding scale of infrastructure required, a typical plasma system requires significant balance-of-system hardware in order to enable self-sustaining electrical power (Ref. 9). An energy-efficient system will include reusing otherwise wasted thermal energy from stage 1 products (i.e., syn-gas at $>1000^{\circ} \mathrm{C}$ ) to drive turbines to generate electricity. This would then be followed by a F-T operation to convert syn-gas (CO and hydrogen) into a product soup of saturated and unsaturated hydrocarbons as well as some oxygenated products such as alcohols of $\mathrm{C} 5$ to C20 or so with some waxy materials. The balance-of-system technology requirements drive up the complexity (and cost) (Ref. 9), and minimize suitability for space applications; in fact, these issues eliminate PAG technology from further consideration. 
TABLE I.-COMPARISON OF RELEVANT METRICS FOR TERTIARY AND QUATERNARY WTE PROCESSES

\begin{tabular}{|l|c|c|c|c|c|c|}
\hline \multicolumn{1}{|c}{$\begin{array}{c}\text { Process } \\
\text { (class) }\end{array}$} & $\begin{array}{c}\text { Temperature } \\
\text { range }\end{array}$ & $\begin{array}{c}\text { Approximate } \\
\text { pressure } \\
\text { (MPa) }\end{array}$ & $\begin{array}{c}\text { Product } \\
\text { output }\end{array}$ & $\begin{array}{c}\text { Technical } \\
\text { complexity }\end{array}$ & $\begin{array}{c}\text { Approach to energy } \\
\text { efficiency or } \\
\text { utilization }\end{array}$ & $\begin{array}{c}\text { Infrastructure } \\
\text { needs }\end{array}$ \\
\hline $\begin{array}{l}\text { Thermal } \\
\text { cracking } \\
\text { (tertiary) }\end{array}$ & 400 to $450{ }^{\circ} \mathrm{C}$ & 4 to 6.9 & $\begin{array}{c}\text { Burning C1-C5 } \\
\text { C1-C5 and mostly } \\
>\mathrm{C}_{6} \text { hydrocarbons } \\
\text { fraction supplies } 80 \% \\
\text { energy }\end{array}$ & Low & Large \\
\hline $\begin{array}{l}\text { Flash cracking } \\
\text { (tertiary or } \\
\text { quaternary) }\end{array}$ & 400 to $600{ }^{\circ} \mathrm{C}$ & 0.1 to 1.0 & $\begin{array}{c}\text { Flexible: } \mathrm{C} 1-\mathrm{C} 10 \\
\text { depending upon } \mathrm{T}, \\
\mathrm{P}, \text { catalyst }\end{array}$ & Medium & $\begin{array}{c}\text { Designed to be low } \\
\text { energy; potential solar } \\
\text { energy use }\end{array}$ & Modest \\
\hline $\begin{array}{l}\text { Steam reforming } \\
\text { (quaternary) }\end{array}$ & $\sim 850^{\circ} \mathrm{C}$ & 0.3 to 0.7 & $\begin{array}{c}\text { Syn-gas }(\mathrm{CO}+ \\
\mathrm{H}_{2} \text { ), } \mathrm{CO}_{2}, \mathrm{CH}\end{array}$ & Medium & $\begin{array}{c}\text { Balancing endothermic } \\
\text { and exothermic } \\
\text { reactions }\end{array}$ & Modest \\
\hline $\begin{array}{l}\text { Plasma assisted } \\
\text { gasification } \\
\text { (quaternary) }\end{array}$ & $\begin{array}{c}\text { Typically } \\
5,000{ }^{\circ} \mathrm{C}\end{array}$ & 0.1 & $\begin{array}{c}\text { Primarily } \\
\text { syn-gas }\end{array}$ & High & $\begin{array}{c}\text { Recovery of thermal } \\
\text { energy from }>1000 \\
\text { syn-gas stream }\end{array}$ & Significant \\
\hline
\end{tabular}

The three remaining technologies to be compared include a chemical recycling technology being developed by (among others) an Akron, Ohio-based start-up company (RES Polyflow) (Ref. 5), flash cracking or pyrolysis (simple or catalytic) (Ref. 10), and an SBIR-funded steam reforming process (Ref. 5). The RES Polyflow pyrolytic process is quite simple but scalability may be an issue (Ref. 5). A flash cracking reactor is quite flexible from a process perspective, and is represented by a system discussed in the literature; the final product mix can be tailored depending upon the temperature and pressure as well as the presence of a catalyst (Ref. 10). The lower energy demand for this process can be met by solar thermal and photovoltaic sources, as discussed below. Pioneer Astronautics has combined two unit operations that work in tandem to produce methane and oxygen. The process is quite scalable and available in 2013 as a prototype unit from a Phase II program. One issue is the need for an external hydrogen source for a Sabatier reactor: this would most likely come from splitting water (Ref. 4). Solar energy as well as efficient thermal energy utilization will be required if this technology is to be considered as a serious flight candidate.

In summary, we have briefly compared four WTE processes to assess their suitability for ISRU: chemical recycling via pyrolysis or flash cracking, combined steam reformation/Sabatier, and plasma assisted gasification followed by (likely) F-T synthesis. Because of the moderate cost, scalability for space applications, energy utilization and technology heritage of the Sabatier process, two tertiary and one quaternary WTE steam processes appear to have potential for further development. There are still balance-of-system issues remaining such as the need for hydrogen to drive the hydrocarbon production processes, safety concerns, and integration of the candidate technology into the mission architecture. The pyrolysis process, a tertiary chemical recycling methodology is technically quite straightforward but has some scaling issues due to the impact of dimensions on process kinetics. Plasma assisted gasification at the trade-study analysis level (Ref. 9) appears to present some fundamental scaling issues that preclude this technology from being further considered for LRR applications.

\section{Stage 2: Processing Supply Gas Into Fuels}

A brief consideration of $\mathrm{C} 1$ and related chemistry provides a context for beginning a discussion of the relevant processing options, systems issues and related technologies that will be addressed below (Ref. 11). C1 chemistry refers to a number of reactions including those that convert simple carboncontaining gases from "Stage 1" processing of trash and waste (mostly carbon dioxide or carbon monoxide) into green and/or ultra-clean aerospace fuels. The enthalpy $(\Delta \mathrm{H})$ change which is related to total Gibbs free energy change of the reaction $(\Delta \mathrm{G}=\Delta \mathrm{H}-\mathrm{T} \Delta \mathrm{S})$ is an indication of whether the 
transformation releases energy (exothermic, negative $\Delta \mathrm{H}$ ) or requires energy input (endothermic, positive $\Delta \mathrm{H})$.

Depending upon the application or desired products, combining endothermic and exothermic reactions minimizes the energy that must be added to the overall system. Several endothermic reactions are available to produce synthesis gas (1) or supply gas (3) from methane, for example. Reactions (1) and (3) are related by combining reaction (1) with the slightly exothermic water gas shift (WGS) reaction (2). These are simplified "model systems" that stand in for carbon-containing waste and/or trash raw materials as discussed above.

$$
\begin{array}{crl}
\mathrm{CH}_{4}+\mathrm{H}_{2} \mathrm{O}=>\mathrm{CO}+3 \mathrm{H}_{2} & \Delta \mathrm{H}=+49 \mathrm{kcal} / \mathrm{mole} \\
\mathrm{CO}+\mathrm{H}_{2} \mathrm{O}=>\mathrm{CO}_{2}+\mathrm{H}_{2} & \Delta \mathrm{H}=-9 \mathrm{kcal} / \mathrm{mol} \\
\mathrm{CH}_{4}+2 \mathrm{H}_{2} \mathrm{O}=>\mathrm{CO}_{2}+4 \mathrm{H}_{2} & \Delta \mathrm{H}=+40 \mathrm{kcal} / \mathrm{mol}
\end{array}
$$

In "stage 2," three exothermic reactions are available to produce hydrocarbons from $\mathrm{CO}$ or $\mathrm{CO}_{2}$ and hydrogen. The Sabatier process (reaction (4)) is the reverse of reaction (3) and is typically catalyzed by $\mathrm{Ni}, \mathrm{Ru}$, or $\mathrm{Rh}$ on oxide supports; and has been a candidate technology for space habitat air revitalization (Ref. 12). In fact, a commercial Sabatier reactor was delivered to the International Space Station by mission STS-131 on April 5, 2010. Methanation (Refs. 13 and 14) (5) and the thermodynamically-related Fischer-Tropsch synthesis (FTS) (Refs. 15 and 16) (6) are also reverse reactions of steam reforming of methane (1); these reactions are catalyzed by $\mathrm{Ni}$ (methanation only), $\mathrm{Co}, \mathrm{Fe}$, and $\mathrm{Ru}$ on various oxides. All three reactions are quite exothermic and can be used to improve the energy balance in an overall system when producing fuels from waste or trash. The recycler/heat exchanger in Figure 1 is a "black box" with several unit operations including a series of systems for the transfer of thermal energy from exothermic processes in stage 2 to provide heat to stage 1 (Ref. 17). Unlike methanation, F-T catalysis produces a range of products, both pure hydrocarbons and oxygenated products, depending upon the catalyst and reaction temperature and pressure.

$$
\begin{array}{cc}
\mathrm{CO}_{2}+4 \mathrm{H}_{2}=>\mathrm{CH}_{4}+2 \mathrm{H}_{2} \mathrm{O} & \Delta \mathrm{H}=-40 \mathrm{kcal} / \mathrm{mol} \\
\mathrm{CO}+3 \mathrm{H}_{2}=>\mathrm{CH}_{4}+\mathrm{H}_{2} \mathrm{O} & \Delta \mathrm{H}=-49 \mathrm{kcal} / \mathrm{mol} \\
\mathrm{n} \mathrm{CO}+(2 \mathrm{n}+1) \mathrm{H}_{2}=>\mathrm{C}_{\mathrm{n}} \mathrm{H}_{(2 \mathrm{n}+2)}+\mathrm{n} \mathrm{H}_{2} \mathrm{O} & \Delta \mathrm{H}=-49 \mathrm{kcal} / \mathrm{mol}(\mathrm{n}=1)
\end{array}
$$

\section{Catalytic Wet Air Oxidation}

Catalytic wet air oxidation (CWAO) is an attractive method for the treatment of waste streams that are too dilute to incinerate $(<40$ percent) (Ref. 6$)$ and too concentrated for biological treatment $(>1$ percent) (Ref. 7). The method involves the oxidation of organic substances in an aqueous suspension by means of air at elevated temperatures and pressures. Heterogeneous catalysts are used to oxidize refractory compounds in the aqueous phase and produce desired products in the gas phase. Typical conditions range from $200{ }^{\circ} \mathrm{C}$ and $2 \mathrm{MPa}$ to $320^{\circ} \mathrm{C}$ and $20 \mathrm{MPa}$.

Catalytic methods such as wet air oxidation or photocatalysis (Ref. 5) may serve as the basis for a system of waste and trash processing, or could be used as part of a suite of supporting or auxiliary technologies to boost the hydrogen content of various gas streams, or in using energy-efficient methods to reduce the volume and/or increase the utilization of solid or by-product streams. In CWAO, a supported metal such as Ru serves as the catalyst for the decomposition of polymers and produces mostly $\mathrm{CO}_{2}$ and $\mathrm{H}_{2}$, and offers additional beneficial functionality.

GRC is currently investigating CWAO as a method to produce methane from waste simulant using various catalysts in a one step process. Kulis et al., have demonstrated that significant amounts of methane can be produced using CWAO of polyethylene terephthalate with Ru as a catalyst (Ref. 18). In 
addition, concentrated solar energy is being investigated as a thermal source, and photocatalysis is being investigated as a supplementary method that would be used to split water in order to produce additional hydrogen for methane production. Though $\mathrm{CO}_{2}$ formation and departure from the catalytic surface is crucial, the kinetics may be dictated in part by such factors as surface tension, surface roughness, and gravity, where a practical understanding of bubble formation and departure may guide design of the CWAO process under reduced gravity conditions.

\section{Balance-of-System Concerns and Resistojet Technology for Gas Utilization}

There are a variety of issues related to the integration of the re-use technologies with the rest of the spacecraft. This section addresses some of those concerns and highlights some GRC capabilities, facilities, and expertise in this area.

\section{Energy Efficiency Issues}

Energy must be considered at a system level, where heat is added to the system for driving the endothermic reactions and heat is harvested from the exothermic reactions for improving overall system efficiency. Overall heat rejection must also be considered. Electric power derived from spacecraft photovoltaics is the most likely source of process energy, including the electrical energy needed for running pumps and splitting water. In certain cases there may be merit in considering solar thermal to augment the process energy, particularly for the stage 1 endothermic reforming reactions ((1) and (3)). Given a Sun-tracking requirement, solar thermal augmentation may best be suited for treatment facilities that are anchored to the lunar or Martian surface rather than part of a spacecraft rotating about its axis for thermal control. Numerous studies have been completed on the various types of solar thermal concepts available for possible use, ranging from rigid structures having facets with high quality optical surfaces and concentration ratios of the order of 8000:1, to concepts that tout light weight inflatable structures, light pipes, and trough systems with lesser efficiency and lesser concentration ratios (Refs. 19 and 20). Perhaps the ideal concept is one where a Sun-tracking trough style solar concentrator anchored to the lunar surface heats the carbon-containing waste and/or trash raw materials in a carrier stream of oxidizer, optimized such that the residence time in the trough enables the heating of the mixture to the desired temperature prior to entering a reaction chamber. Small diameter thick walled tubing coated with a high absorptance coating and located at the focus of the trough would enable high pressure high temperature operation, particularly for the CWAO process.

Initial research is now underway to consider solar thermal augmentation for process energy and selected on-Sun testing has been performed on a test article that simulates a stainless steel tube at the focus of a high efficiency concentrator. The concentrator utilized here is of a Cassegrainian design and is described in detail elsewhere (Ref. 21). The concentrator was located on a platform equipped with Suntracking hardware. The test article consisted of a thick-walled stainless steel tube which offers the advantage of pressure containment, however, thermal conductivity is a problem. The use of a copper jacket to distribute the heat around the perimeter of the tube was considered here, and the stainless steel tube was purposely surrounded by a press-fit copper jacket. The test article was instrumented with thermocouples and was purposely surrounded by multilayer insulation to minimize heat loss. In practice, the tubing would be sized to accommodate the flow of carbon-containing waste and trash, and the mass rate of flow along with any endothermic reactions would serve to draw heat away from the region illuminated by the concentrator. Here, the test article here was open to the air. The copper jacket was painted black, to enhance solar absorption and Figure 2 summarizes the fabrication of the test article, reveals the concentrated sunlight as a spot on the surface of the black paint, and shows an excerpt of the on-Sun heating data. 

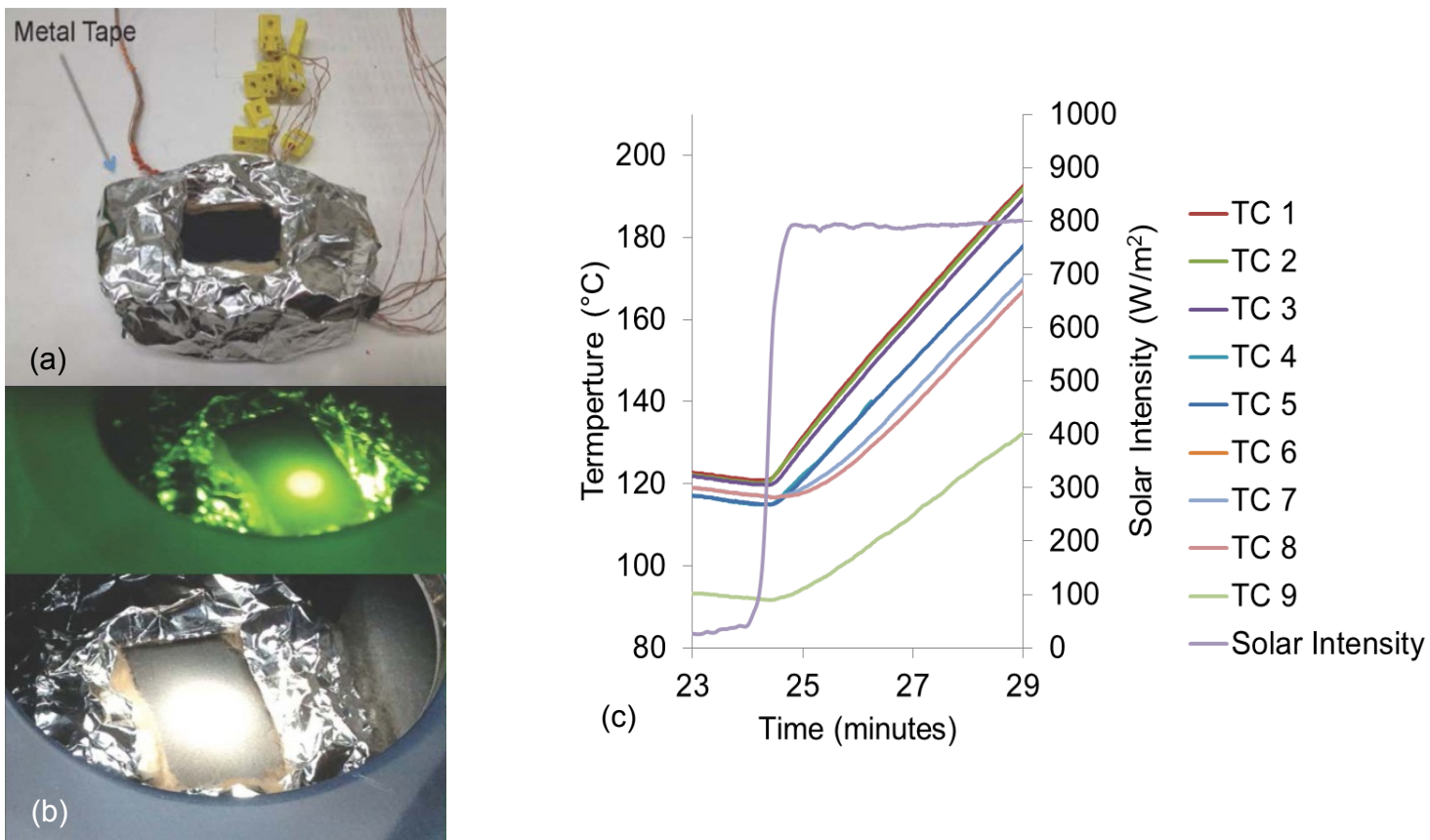

Figure 2.-Copper-jacketed stainless steel test article, (a) painted, instrumented, and enclosed in insulation, (b) under concentrated sunlight (the glare is removed by viewing through a filter), and (c) an excerpt of the on-Sun data. Note: the majority of the energy impinging on the copper is within a small spot.

Conclusions from the on-Sun testing are summarized here, briefly. The test article had been on-Sun for several minutes, though the day was partly cloudy and the excerpt shows the Sun beginning to impinge on the test article again after being cloud-covered. Thermocouples 1 and 2 were located on one side of the copper jacket, 5 and 6 were on the opposite side ( 6 malfunctioned), 3 and 4 were on the back, and 7 and 8 were on the exterior of the stainless steel tube some distance from the copper jacket.

Thermocouple 9 was located inside the stainless steel pipe. Under ideal system-level operation, the solar thermal augmentation would ideally reach steady state, such that the energy entering the system from the impinging sunlight just equals the amount of energy departing the illuminated region in the form of mass flow and endothermic reactions. The results from the on-Sun testing revealed 1) the copper jacket was only partially successful at distributing the heat around the tubing and 2) the interior temperature lagged behind due to the thick-walled nature of the stainless steel. As can be seen, it takes many tens of minutes for the test article to heat under the influence of the concentrated sunlight. All these observations suggest that the ideal system will need an adequate solar tracking system as a minimum, a trough concentrator is likely preferred in order to avert the need for distributing heat utilizing a copper jacket, and perhaps the most important need is a well anchored solar concentrator.

The shuttling of excess heat from exothermic reactions to power endothermic reactions may be possible utilizing conventional heat pipes or heat exchangers designed to deliver such energy from one location to another. However, a temperature gradient is needed in such systems, the processing temperatures may limit such a concept, and losses are inevitable. Heat pumps are available to shuttle excess heat from one location to another, with the added feature of increasing the temperature at the outlet. Of course, heat pumps represent an electric load on the system and must be incorporated into any energy balance study. Perhaps the ideal concept is one where sufficient electrical power is provided to the reactor into which reactants are provided to overcome the sensible heat of the reactor mass and the energy needed to initiate stage 1 endothermic reactions during transient start up operations, and electrical power is throttled back as new solar thermal heat sources are brought on line during steady state operation. Repeated transient and steady state operation should be expected for either batch or continuous processing, though far fewer cycles would be anticipated for a continuous reactor. 


\section{Methods of Handling Heteroatom Impurities}

Upon consideration of the recycling of trash and waste materials, a technological hurdle that must be surmounted is separation and storage of impurities. In our previous paper, we discussed specific technologies being addressed by several co-authoring organizations to remove metals, nitrogen, sulfur, and halogens present in packaging materials and human wastes (Ref. 5). If not removed, these materials pose potential health hazards to the crew and destructive impact on various components and subsystems in the closed waste and trash reprocessing system by material corrosion and catalyst poisoning.

There are basically two approaches to the removal of impurity compounds (oxides, hydrides, sulfides, halocarbons): methods involving little or no power that consist of adsorbing and long-term storage of impurities, possibly including recharging or re-activation of sorbant materials, or active methods involving solar, electrical and/or thermal energy to decompose impurities to simpler species, one or more of which can be re-used such as water, oxygen, or hydrogen. Table II summarizes and compares several methods to recycle a variety of impurity materials from gas streams of both types.

Of the six methods compared in Table II, the first two methods are the most problematic owing to potential mechanical or biological impact on the environment, particularly a closed system. They are also difficult to integrate into a processing system (Figure 1). The four methods that primarily rely on catalytic processes and/or adsorbant materials use lower amounts of a likely limited power supply and could be more readily integrated into a recycling function in a processing system. Utilization of solar energy directly or indirectly through electricity generated by photovoltaics would also have advantages in the energy balance as discussed above.

TABLE II.-COMPARISON OF METHODS FOR SEPARATION OF IMPURITIES FROM GAS STREAMS

\begin{tabular}{|c|c|c|c|c|c|}
\hline Process & Energy Requirements & Impurity(ies) & Products & Comment(s) & $\begin{array}{l}\text { Literature } \\
\text { references }\end{array}$ \\
\hline \begin{tabular}{|l} 
Centrifugal \\
$>30,000 \mathrm{rpm}$ \\
\end{tabular} & Electrical-large & $\begin{array}{c}\mathrm{H}_{2} \mathrm{~S} \text { and } \mathrm{CO}_{2} \text { in } \\
\mathrm{CH}_{4}\end{array}$ & $\begin{array}{c}\mathrm{H}_{2} \mathrm{~S} \text { and } \mathrm{CO}_{2} \\
\text { removed }\end{array}$ & $\begin{array}{l}\text { Not suitable for space } \\
\text { station }\end{array}$ & 22 \\
\hline $\begin{array}{l}\text { Biofilters in aqueous media: } \\
\text { bacterial, wood, textile, } \\
\text { sand, or combination }\end{array}$ & Electrical-minimal & $\begin{array}{c}\left.\mathrm{NH}_{3} \text { (and } \mathrm{H}_{2} \mathrm{~S}\right) \\
\text { in air }\end{array}$ & $\begin{array}{c}\mathrm{NH}_{3} \text { (and } \\
\left.\mathrm{H}_{2} \mathrm{~S}\right) \\
\text { removed }\end{array}$ & $\begin{array}{l}\text { Must be crew bio- } \\
\text { compatible }\end{array}$ & 23 to 25 \\
\hline Filtering by zeolites & $\begin{array}{l}\text { Thermal-minimal to } \\
\text { reactivate }\end{array}$ & $\begin{array}{l}\text { Volatile organic } \\
\text { compounds } \\
\text { (VOCs) in air }\end{array}$ & $\begin{array}{l}\text { VOCs } \\
\text { removed }\end{array}$ & $\begin{array}{l}\text { May require heating to } \\
\text { reactivate active } \\
\text { adsorbants }\end{array}$ & 26 \\
\hline $\begin{array}{l}\text { Oxide catalyst \& } \\
\text { Metal/zeolite filter }\end{array}$ & $\begin{array}{l}\text { Thermal - moderate for } \\
\text { Temp }>400{ }^{\circ} \mathrm{C}\end{array}$ & $\begin{array}{l}\text { Carbon, VOCs, } \\
\mathrm{NO}_{\mathrm{x}} \text {, and } \mathrm{CO} \text { in } \\
\text { air }\end{array}$ & $\mathrm{CO}_{2}$ and $\mathrm{N}_{2}$ & $\begin{array}{l}\text { Useful process for } \\
\text { recycling by-products }\end{array}$ & 27 \\
\hline $\begin{array}{l}\text { Photocatalysis } \\
\mathrm{TiO}_{2} / \text { aluminum silicate } \\
\text { fiber }\end{array}$ & $\begin{array}{l}\text { Solar energy with UV } \\
\text { photons }\end{array}$ & $\begin{array}{c}\mathrm{SO}_{2}, \mathrm{NO} \text { and } \\
\mathrm{Hg}^{0} \text { in air }\end{array}$ & $\begin{array}{c}\text { Pollutants } \\
\text { removed }\end{array}$ & $\begin{array}{l}\text { Passive relies on } \\
\text { ambient solar } \\
\text { irradiation }\end{array}$ & 28 \\
\hline $\begin{array}{l}\text { Catalytic } \mathrm{H}_{2} \mathrm{~S} \text { splitting by } \\
\text { solar thermal, } \\
\text { photochemical, } \\
\text { electrochemical, or } \\
\text { combination of methods } \\
\end{array}$ & $\begin{array}{l}\text { Solar energy to provide } \\
\text { photons, heat, or } \\
\text { electricity; geared } \\
\text { towards renewable } \\
\text { energy usage }\end{array}$ & $\mathrm{H}_{2} \mathrm{~S}$ & $\mathrm{H}_{2}+$ sulfur & $\begin{array}{l}\text { Very flexible family of } \\
\text { methods; details } \\
\text { dependent upon } \\
\text { catalyst and available } \\
\text { energy }\end{array}$ & 29 and 30 \\
\hline
\end{tabular}

\section{Resistojet Propulsion Option}

As part of the LRR program, the production of fluids (liquids and gases) from the waste materials aboard a space vehicle may be many and varied. These fluids can be used in a propulsion option called the resistojet. The resistojet is a form of electric propulsion known as an electrothermal thruster, where power is provided to the thruster to vaporize and heat the propellant to high temperature, and then the hot gas is passed through a converging-diverging deLaval nozzle, expanding the gas to supersonic velocities (Refs. 31 to 37). The heating of the fluid provides much higher exhaust velocity (or specific impulse) than if the fluid were used in the cold gas mode without heating. The resistojet can accommodate many different fluids. 


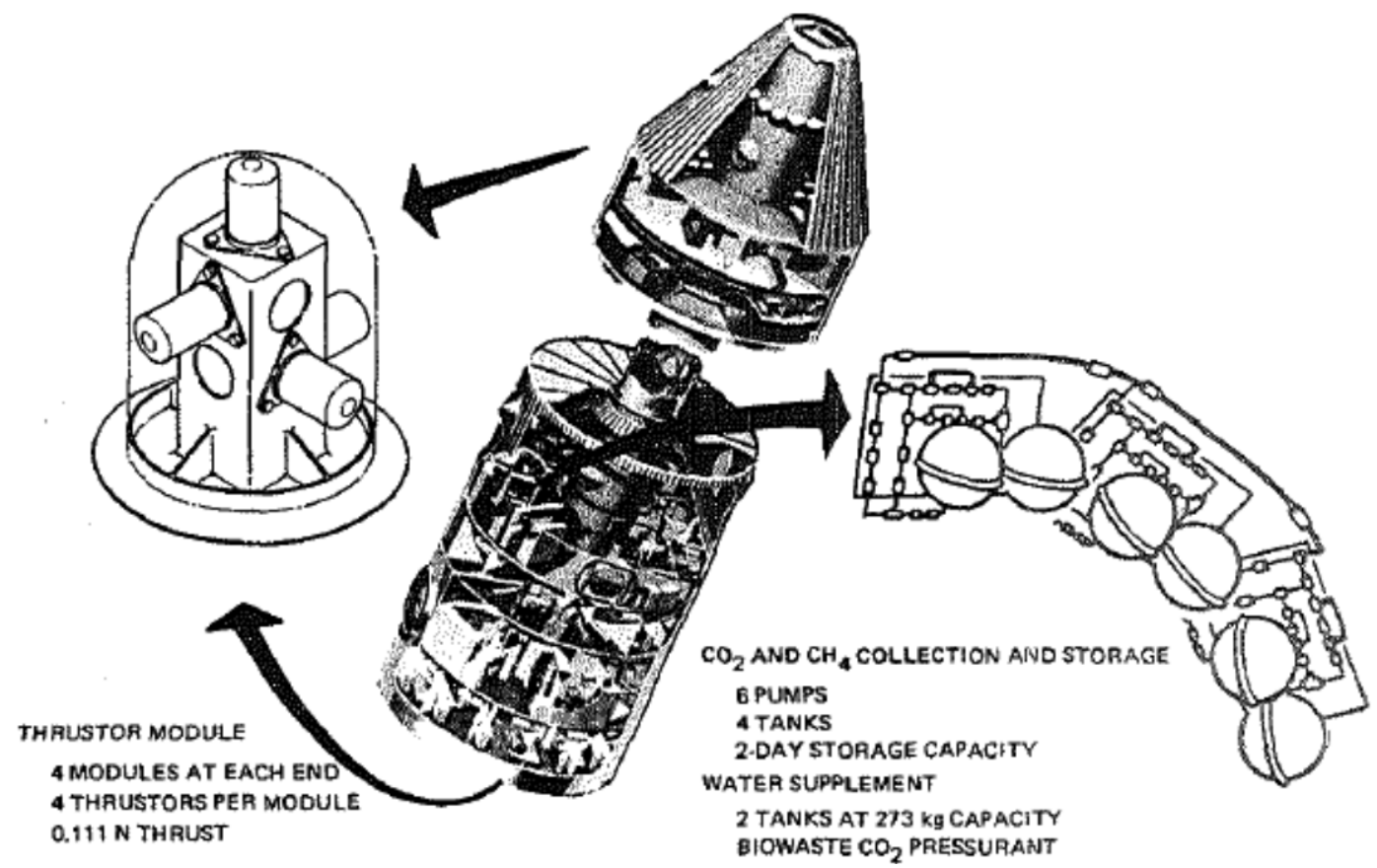

Figure 3.-Diagram of resistojet propulsion technology from 1970s (Refs. 31 and 32).

\section{0s Resistojet Research}

During the study phase of several space station concepts, the idea of using the waste fluids from the space station was considered. Resistojet propulsion was investigated and the extensive design showed some benefits and drawbacks. Figure 3 shows an overall configuration of the resistojet system. The integration of the propulsion system with the station layout of the components is noted. The design model of a space station resistojet system uses environmental control life support system (ECLSS)-produced biowaste gases $\left(\mathrm{CO}_{2}\right.$ and $\left.\mathrm{CH}_{4}\right)$ as propellants (Refs. 31 and 32) on the station. The gases are used separately, and water is employed as a propellant supplement. The system minimizes resupply requirements, furnishes a useful method of biowaste disposal, minimizes contamination, and permits near-zero acceleration, reducing the thruster disturbances on the space station.

The resistojets have a thrust level of 0.1 Newton $(0.025 \mathrm{lb}-\mathrm{f})$ and are operated in a high-duty-cycle mode ( 25 to 80 percent) for space station orbit-keeping and control moment gyroscope (CMG) desaturation. The thrusters are mounted in modules. Four modules are located at each end of the space station, and the gas storage tanks are housed in the pressurizable forward compartment (Ref. 31).

The major components of the system are compression pumps, heat exchangers, accumulators, propellant tankage, thrusters, and the necessary valves and switches for control and checkout. The system weighs $259 \mathrm{~kg}(570 \mathrm{lb}-\mathrm{m})$, occupies a volume of $2.78 \mathrm{~m}^{3}\left(100 \mathrm{ft}^{3}\right)$, and requires 100 to $400 \mathrm{~W}$ of electrical power (Ref. 31).

The space station biowaste resistojet propulsion system was required to operate automatically, with little or no crew participation except for maintenance and repair, etc. Thus, system control was required to acquire stabilization and attitude control (S\&AC) data, calculate impulse requirements, determine propellant utilization and provide the necessary operating commands; typically once per orbit. Furthermore, the interface with the ECLSS (propellant supply) and the high duty cycle and usage (25 to 80 percent each orbit) makes operational control significantly different and more complex than conventional systems (Ref. 31). 


\section{0s Resistojet Research}

As space station concepts moved toward reality, many propulsion options were considered. Resistojet propulsion seemed a natural choice in that many gases were produced by the many systems on the planned Space Station Freedom. A detailed set of all waste gases and fluids were identified: from life support systems, cooling systems, and cryogenic experiment gases the resistojet could use those fluids for space station orbital reboost (Ref. 33). Extensive engineering model testing was conducted and detailed requirements were developed for resistojet propulsion for Space Station Freedom. Figure 4 depicts the orbital replacement units (ORUs) for the resistojet propulsion system. Figure 5 shows the resistojet engineering model tested by NASA for the space station. Extensive testing of the engineering model engine with the various waste gases helped identify the platinum and yttria alloys needed to survive the oxidizing and reducing environments (Refs. 34 to 37).

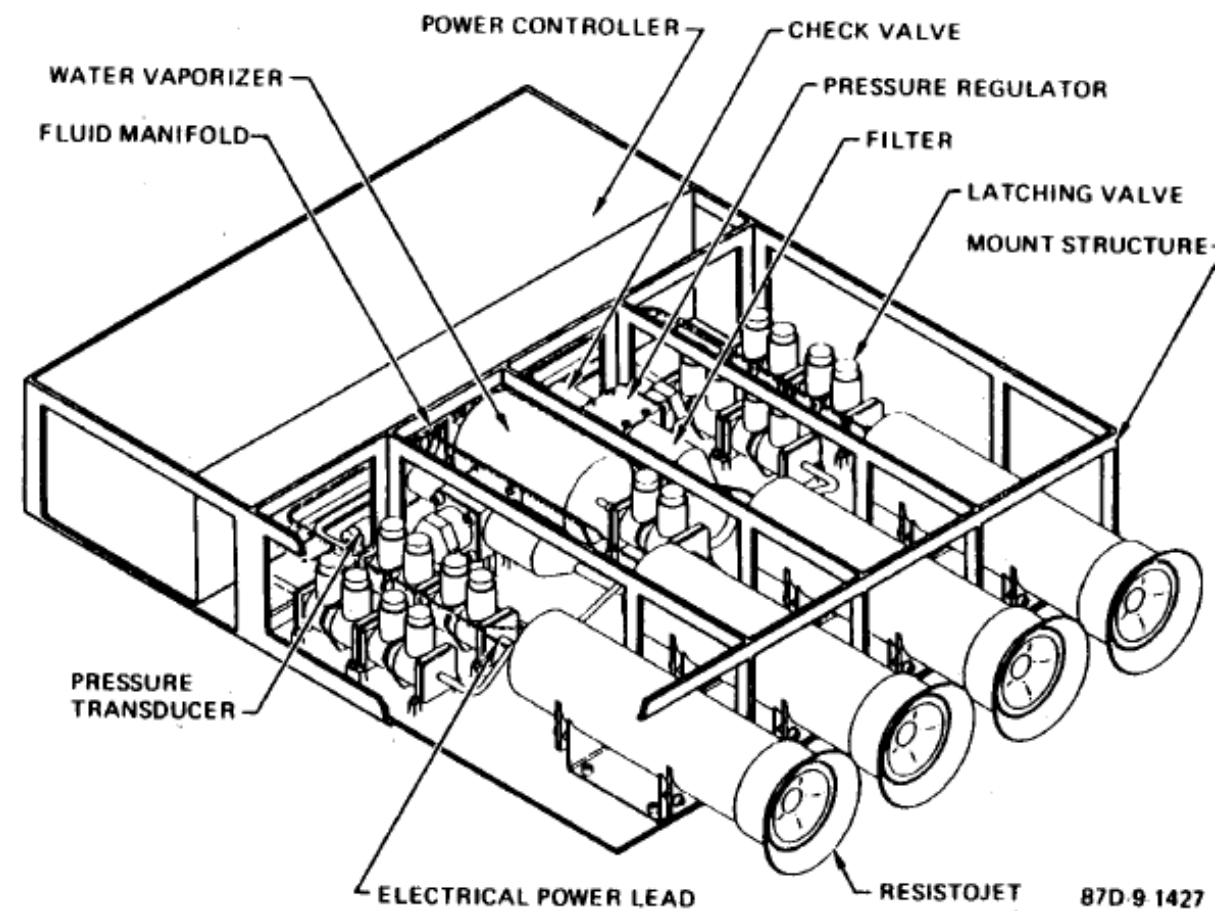

Figure 4.-Resistojet orbital replacement unit (ORU, Ref. 33).

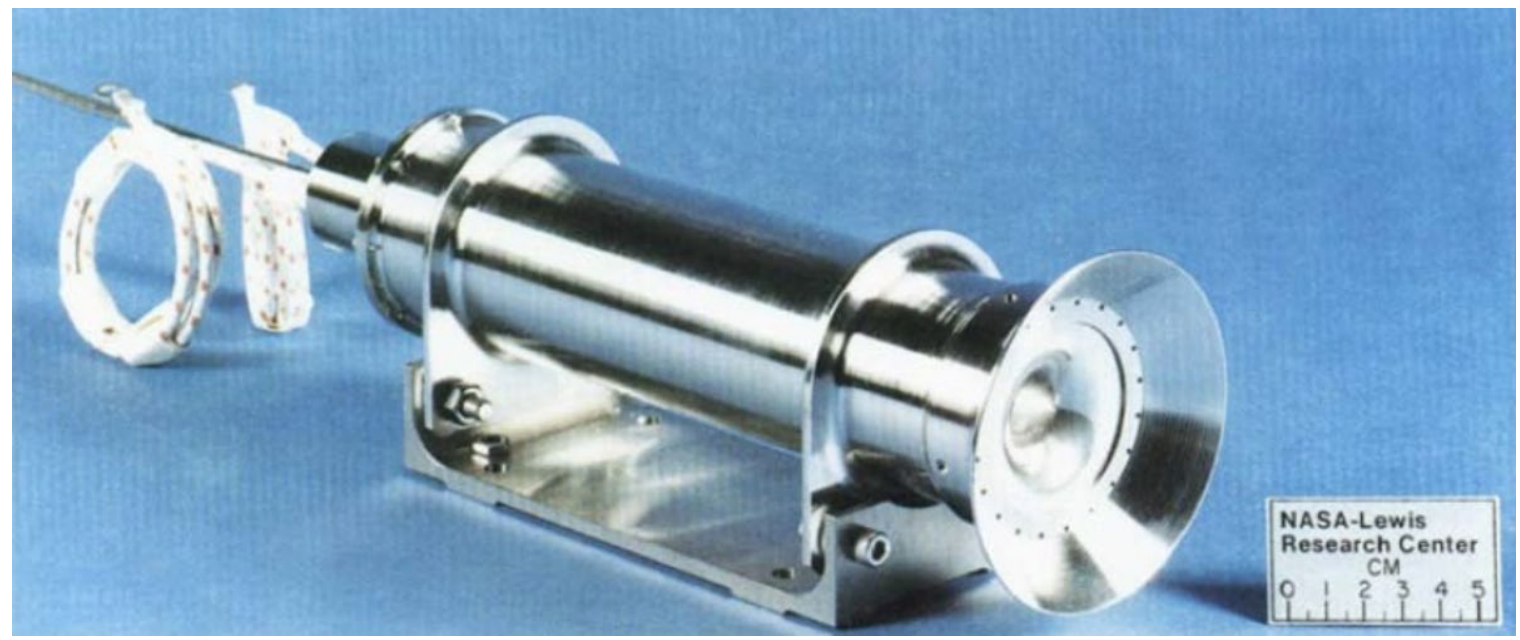

Figure 5.-Resistojet thruster engineering development model (Ref. 34). 


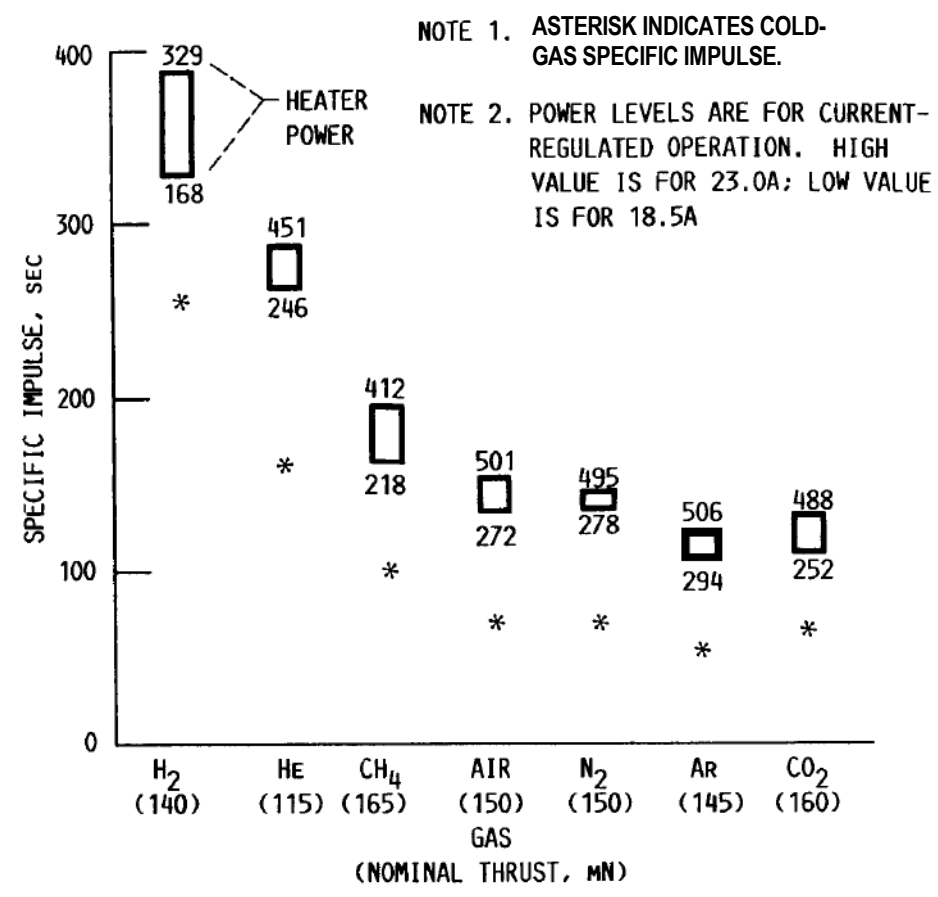

Figure 6.-Resistojet propulsion performance, experimental data (Ref. 35).

Figure 6 shows the numerous bio-waste propellants that the resistojet can use. Their engine specific impulse and other performance parameters (heater power level, thrust levels, etc.) are noted. The cold gas specific impulse for the hydrogen resistojet is approximately $380 \mathrm{sec}$ at a power level of $329 \mathrm{~W}$. In comparison, the cold gas hydrogen performance (with no heater power) is $250 \mathrm{sec}$ (Ref. 35).

\section{Gateway Propulsion Needs}

While the Gateway vehicle is still at the preliminary design stage, several options have been discussed. Figure 7 depicts a configuration and provides a mass summary of two such preliminary designs for 60 and 500 day stays in space. These mass estimates show all of the vehicle subsystems but not the required propulsion system masses. Based on the final mission design, additional masses for the propulsion system dry mass (tankage, feed systems, etc.), the required propellant mass and other vehicle interfaces will be required.

\section{LRR and Resistojet Propulsion}

While the planned human space vehicles are not as ambitious as large space stations, the propulsion system use of the waste gases on such future vehicles can still be advantageous. Aboard the Gateway (Earth-Moon libration point station) or other space vehicle a heat melt compactor (HMC), or other waste processing technologies, operated by the astronauts would process the waste materials. The fluids that may be produced would be water, methane, methanol, oxygen, etc. Past resistojet propulsion studies and experiments have shown that the resistojet can use a wide range of fluids and also mixtures of those fluids. By eliminating the need to separate specific fluids, the use of the waste material fluid products can be simplified significantly. 


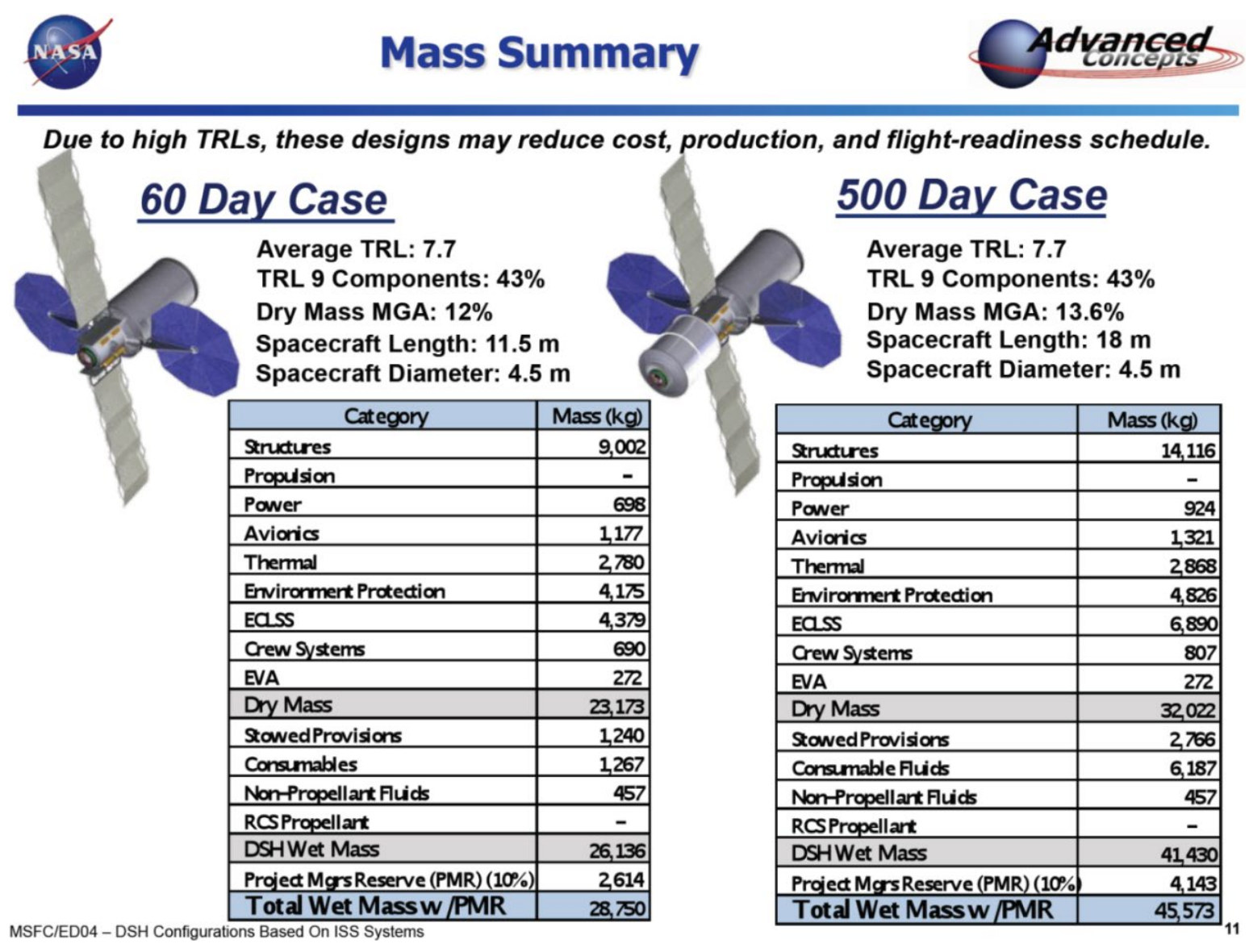

Figure 7.-Notional design for Gateway vehicles (Ref. 38).

\section{Conclusion}

Plastic solid waste can be recycled or utilized via four major classes of processes with increasing physical and/or chemical breakdown. Relevant to this discussion are chemical recycling (tertiary) and energy recovery (quaternary). Depending upon desired products and mission, combining endothermic and exothermic reactions minimizes energy that must be added to the overall system. A technological hurdle that must be surmounted is separation and storage of impurities. On future space vehicles, an array of potential waste fluids has been identified. These fluids may be produced using innovative processes such as heat melt compactors, catalysts, reactor technologies, solar energy, and other green power sources, for solid waste processing. Other than fluids for life support and cooling, many propulsion requirements can be met with the more energetic fluids. The delta-V and other propulsion requirements can use the captured waste fluids effectively in a low-thrust rocket engine such as a resistojet. This form of electric propulsion can accommodate many types of fluids or mixtures of fluids. While there are many processes to consider, the final selection will be based on a combination of efficiency, complexity, astronaut safety, and consumption of the astronauts' valuable time in space.

\section{References}

1. Huntress, W., Stetson, D., Farquhar, R., Clark, B., O'Neil, W., Bourke, R., and Foing, B., "The Next Steps in Exploring Deep Space - A Cosmic Study by the IAA," Acta Astronaut., Vol. 58, No. 6-7, 2006, pp. 304-377. 
2. Lewis, J., Matthews, M. S., and Guerrieri, M.L. (eds.), Resources of Near-Earth Space, The University of Arizona Press, Tuscon, AZ, 1993, pp. 3-17.

3. Al-Salem, S.M., Lettieri, P., and Baeyens, J., "The Valorization of Plastic Solid Waste (PSW) by Primary to Quaternary Routes: From Re-Use to Energy and Chemicals," Prog. Energy Combust. Sci., Vol. 36, No. 1, 2010, 103-129.

4. Hepp, A.F., Linne, D.L., Groth, M.F., Landis, G.A. and Colvin, J.E., "Production and Use of Metals and Oxygen for Lunar Propulsion,” J. Prop. Power, Vol. 10, No. 6, 1994, pp. 834-840.

5. Hepp, A.F., Kulis, M.J., De La Ree, A.B., Zubrin, R., Berggren, M., Hensel, J.D., and Kimble, M.C., "Green Aerospace Fuels from Non-Petroleum Sources," 49th Aerospace Sciences Meeting, Paper AIAA 2011-702, NASA/TM-2011-217027, 2011.

6. Fytili, D. and Zabaniotou, A., "Utilization of Sewage Sludge in EU Application of Old and New Methods - A Review," Renew. Sust. Energy Rev., Vol. 12, No. 1, 2008, pp. 116-140.

7. Znad, H., Kasahara, N., and Kawase, Y., "Biological Decomposition of Herbicides (EPTC) by Activated Sludge in a Slurry Bioreactor," Proc. Biochem., Vol. 41, No. 5, 2006, pp. 1124-1128.

8. Kopyscinski J., Schildhauer T.J., Biollaz S.M.A., "Production of Synthetic Natural Gas (SNG) from Coal and Dry Biomass - A Technology Review from 1950 to 2009," Fuel, Vol. 89, No. 8, 2010, pp. 1763-1783.

9. Ducharme, C., "Technical and Economic Analysis of Plasma-Assisted Waste-to-Energy Processes," M.S. Dissertation, Department of Earth and Environmental Engineering, Columbia University, New York, 2010.

10. Lappas, A.A., Samolada, M.C., Iatridis, D.K., Voutetakis, S.S., and Vasalos, I.A., "Biomass Pyrolysis in a Circulating Fluid Bed Reactor for the Production of Fuels and Chemicals," Fuel, Vol. 81, No. 16, 2002, pp. 2087-2095.

11. Peña, M.A., Gómez, J.P., and Fierro, J.L.G., "New Catalytic Routes for Syngas and Hydrogen Production, "Appl. Catal. A, Vol. 144, No. 1-2, 1996, pp. 7-57.

12. Brooks, K.P., Hu, J., Zhu, H., and Kee, R.J., "Methanation of Carbon Dioxide by Hydrogen Reduction Using the Sabatier Process in Microchannel Reactors," Chem. Eng. Sci. Vol. 62, No. 4, 2007, 1161-1170.

13. Eckle, S., Augustin, M., Anfang, H.-G., and Behm, R.J., "Influence of the Catalyst Loading on the Activity and the CO Selectivity of Supported Ru Catalysts in the Selective Methanation of CO in $\mathrm{CO}_{2}$ Containing Feed Gases," Catal. Today, Vol. 181, No. 1, 2012, pp. 40-51.

14. Liu, Z., Chu, B., Zhai, X., Jin, Y., and Cheng, Y., "Total Methanation of Syngas to Synthetic Natural Gas over Ni Catalyst in a Micro-Channel Reactor," Fuel, Vol. 95, No. 1, 2012, pp. 599-605.

15. Khodakov, A.Y., Chu, W., and Fongarland, P., "Advances in the Development of Novel FischerTropsch Catalysts for Synthesis of Long-Chain Hydrocarbons and Clean Fuels," Chem. Rev., Vol. 107, No. 5, 2007, pp. 1692-1744.

16. Davis, B.H., "Fischer-Tropsch Synthesis: Comparison of Performances of Iron and Cobalt Catalysts," Ind. Eng. Chem. Res., Vol. 46, No. 26, pp. 8938-8945.

17. Cheremisinoff, N.P., Handbook of Chemical Processing Equipment, Butterworth-Heinemann, Oxford, England, UK, 2000, Chapter 1.

18. Kulis, M.J., Guerrero-Medina, K.J., and Hepp, A.F., "Development of a Catalytic Wet Air Oxidation Method to Produce Feedstock Gases from Waste Polymers," NASA/TM-2012-217405, April 2012.

19. Gordon, P.E., Colozza, A.J., Hepp, A.F., Heller, R.S., Gustafson, R., Stern, T. and Takashi, N., "Thermal Energy for Lunar In-situ Resource Utilization: Technical Challenges and Technology Opportunities," NASA/TM-2011-217114, AIAA-2011-704, October 2011.

20. Jaworske, D.A., Colozza, A., and Sechkar, E.A., "Design for On-Sun Evaluation of Evaporator Receivers," ${ }^{\text {th }}$ International Energy Conversion Engineering Conference, San Diego, CA, AIAA2011-5719, August, 2011.

21. Colozza, A.J., Macosko, R., Castle, C., Sacksteder, K., Suzuki, N.H., and Mulherin J., "Casegrain Solar Concentrator System for ISRU Material Processing," 50th AIAA Aerospace Sciences Meeting, AIAA-2012-0637, January 2012. 
22. Golombok, M. and Chewter, L., "Centrifugal Separation for Cleaning Well Gas Streams," Ind. Eng. Chem. Res., Vol. 43, No. 7, 2004, pp. 1734-1739.

23. De Clippeleir, H., Courtens, E., Mosquera, M., Vlaeminck, S.E., Smets, B.F., Boon, N., and Verstraete, W., Environ. Sci. Technol., Vol. 46, No. 16, 2012, pp. 8826-8833.

24. Tao, J., Manci, K.M., and Tuovinen, O.H., "Attenuation of Pollutants in Sanitary Sewer Overflow: Comparative Evaluation of Treatment with Fixed Media Bioreactors," Bioresour. Technol., Vol. 101, No. 6, 2010, pp. 1781-1786.

25. Lim, T.-T., Jin, Y., Ni, J.-Q., and Heber, A.J., "Field Evaluation of Biofilters in Reducing Aerial Pollutant Emissions from a Commercial Pig Finishing Building,” Biosyst. Eng., Vol. 112, No. 3, 2012, pp. 192-201.

26. Aguado, S., Polo, A.C., Bernal, M.P., Coronas, J., and Santamaría, J., "Removal of Pollutants from Indoor Air using Zeolite Membranes,” J. Membr. Sci., Vol. 240, No. 1-2, 2004, pp. 159-166.

27. Liu, J., Xu, J., Zhao, Z., Duan, A., Jiang, G., and Jing, Y., “A Novel Four-Way Combining Catalyst for Simultaneous Removal of Exhaust Pollutants from Diesel Engine," J. Environ. Sci., Vol. 22, No. 7, 2010, pp. 1104-1109.

28. Yuan, Y., Zhang, J., Li, H., Li, Y., Zhao, Y., and Zheng, C., "Simultaneous Removal of $\mathrm{SO}_{2}, \mathrm{NO}$, and Mercury Using $\mathrm{TiO}_{2}$-Aluminum Silicate Fiber by Photocatalysis," Chem. Eng. J., Vol. 192, 2012, pp. 21-28.

29. Zaman, J. and Chakma, A., "Production of Hydrogen and Sulfur from Hydrogen Sulfide," Fuel Process. Technol., Vol. 41, No. 2, 1995, pp. 159-198.

30. Ma, G., Yan, H., Shi, J., Zong, X., Lei, Z., and Li, C., "Direct Splitting of $\mathrm{H}_{2} \mathrm{~S}$ into $\mathrm{H}_{2}$ and $\mathrm{S}$ on CdSbased Photocatalyst Under Visible Light Irradiation,” J. Catal., Vol. 260, No. 1, 2008, pp. 134-140.

31. Greco, R.V., "Resistojet System Studies Directed Toward the Space Station/Space Base," McDonnell Douglas Corp., MDC-G2125, NASA CR-111878, April 1971.

32. Greco, R.V., "Development of a Biowaste Resistojet Propulsion System," McDonnell Douglas Corp., MDC-G4745, NASA CR-132269, Final Report, Prepared under Contract No. NAS1-10961, July 1973.

33. Heckert, B.J., "Space Station Resistojet System Requirements and Interface Definition Study," Rockwell International, NASA CR-179581, Final Report, Prepared under Contract No. NAS324658, February 1987.

34. Whalen, M.V., "Space Station Resistojets: The Compatibility of Dispersion-Strengthened Platinum with Candidate Propellants," Platinum Metals Rev., Vol. 32, No. 1, 1988, pp. 2-10.

35. Morren, W.E., Hay, S.S., Haag, T.W. and Sovey, J.S. "Preliminary Performance Characterizations of an Engineering Model Multipropellant Resistojet for Space Station Application," NASA TM100113, AIAA-87-2120, July 1987.

36. Morren, W.E. and Stone, J.R. "Development of a Liquid-Fed Water Resistojet," AIAA-88-3288, NASA TM-100927, July 1988.

37. Penko, P.F., Staiger, P.J., and Bur, M.J., "An Analysis of Low-Thrust Resistojet Reboost for the Space Station," AIAA-85-2042, October 1985.

38. Smitherman, D., "Deep Space Habitat Configurations Based on International Space Station Systems," Future In-Space Operations Presentation, Space Systems Team, Advanced Concepts Office, NASA Marshall Space Flight Center, March 14, 2012. 

